\title{
Ruminal Degradability and Bypass Nutrients of Alkaline or Steam-Treated Cassava Chip and Corn Grain
}

\author{
W. Srakaew ${ }^{\mathrm{a}}$, C. Wachirapakorn ${ }^{\mathrm{a}, *}$, A. Cherdthong ${ }^{\mathrm{a}}$, \& C. Wongnen ${ }^{\mathrm{b}}$ \\ a'Department of Animal Science, Faculty of Agriculture, Khon Kaen University, Khon Kaen 40002, Thailand \\ bSchool of Agricultural Technology and Food Industry, Walailak University, \\ Nakhon Si Thammarat 80160, Thailand \\ *Corresponding author: chal_wch@kku.ac.th \\ (Received 05-03-2021; Revised 18-06-2021; Accepted 28-06-2021)
}

\begin{abstract}
Modification of starches in high-energy feeds using various treatment methods led to the diverse effects on ruminal degradation and bypass protein and starch. Thus, the objectives of the present experiment were to investigate the effects of modification methods applied to high-starch energy feed sources on ruminal degradability and bypass nutrients determined using in situ and in vitro gas production techniques. This experiment was designed using a $2 \times 4$ factorial arrangement in a completely randomized design (CRD). The first factor was high-starch energy feed consisted of two levels, i.e., corn grain and cassava chips. The second factor was the treating method consisted of four levels, i.e., no treatment, steam treatment, $\mathrm{NaOH}$ treatment, and steam with $\mathrm{NaOH}$ treatment. Chemical composition, ruminal in situ disappearance, bypass of crude protein (CP) and non-fiber carbohydrate (NFC), and gas production characteristics were measured in pre-treated and posttreated samples. The results showed that significant interactions $(p<0.01)$ between high-starch energy feed sources and treating methods were observed with respect to $\mathrm{CP}$, ether extract (EE), and NFC, dry matter degradability (DMD), effective degradation (ED), and effective gas production (EP). Cassava chips had lower CP and EE but higher NFC, DMD, ED, and EP $(p<0.01)$ compared with corn grain. Treating methods have no influence on $C P$ and EE $(p>0.05)$ in cassava chips and corn grain. DMD, ED, and EP of treated cassava chips were lower, while bypass CP and bypass NFC of treated cassava chips were higher than untreated cassava chips $(p<0.05)$. On the contrary, treated corn grain led to higher DMD, ED, and EP, but lower bypass CP and bypass NFC than untreated corn grain did $(\mathrm{p}<0.01)$. DMD and gas production characteristics in cassava chips and corn grain showed significant correlations between in situ nylon bags and in vitro gas production techniques within each high-starch energy feed source. In conclusion, steam and $\mathrm{NaOH}$ treatments are two alternative methods that can modify the starches of high-starch energy feeds to alter ruminal degradation by decreasing solubility and degradability in cassava chips but increasing degradability in corn grain.
\end{abstract}

Keywords: cassava chips; corn grain; bypass starch; steam treatment; $\mathrm{NaOH}$ treatment

\section{INTRODUCTION}

Starch is an important non-fiber carbohydrate (NFC) component that must be balanced between degradation in the rumen and digestion in the small intestine to provide energy to ruminal microorganisms and ruminants. In Thailand, high-starch energy feeds, including ground corn and cassava chips, are typically used in beef and dairy cattle diets (Pilachai et al., 2012). Cassava chips and corn grain starches have inherent differences in terms of ruminal solubility and fermentability. Their different starch degradation capacities depend on grain kernel structure, pericarp, amylose to amylopectin ratio, and other nutrients such as protein, fat, and fibers found in cassava chips or corn grain (Singh et al., 2013). The starches in cassava chips are high in amylopectin, low in protein and fat, and without pericarp, whereas the starches in corn grain are high in amylose, protein, and fat contents and contain pericarp and cuticle protein (Sarocha et al., 2018). Kanjanapruthipong et al. (2001) report that cassava chips contain $80.16 \%$ NFC are easily degraded within the rumen and 2-3 times more degraded than cornmeal (65.41\% NFC). Cassava starch is highly soluble and rapidly degradable in the rumen at over $90 \%$, whereas corn starch is only $40 \%-60 \%$ degraded in the rumen (Sommart et al., 2000). The strong pericarp and cuticle protein around the seed with starch-protein or starch-fat bonding in corn grain may limit starch degradation in the rumen. As for cassava chips, the absence of protein cuticle and high amylopectin content results in high solubility and rapid degradation in the rumen. This affects rumen ecology when using high amounts of cassava chips in ruminal diets, as the rapidly fermentable starch increases lactic acid production in 
the rumen, resulting in a low $\mathrm{pH}$ value, and may predispose animals to rumen acidosis (Aschenbach et al., 2011; Metzler-Zebeli et al., 2013). Recently, Pilachai et al. (2014) noted that the treatment of cassava chips with $1 \%$ lactic acid (LA) decreased the degradation rate of DM and starch under in vitro studies. This result is in line with those reported by Pilachai et al. (2017), who indicated that the use of LA-treated cassava versus untreated cassava in rations with a high proportion of cassava could prevent rumen acidosis. In addition, differences in suitable levels of ruminal degradability between corn grain and cassava chips are the main reason for researching a treatment to break down the strong cuticle structure in corn grain, thereby reducing the solubility of starch in cassava chips to optimize degradability in the rumen. Many previous studies have shown that the chemical structure of grain undergoes various changes during processing. For example, the ratios of amylose and amylopectin contents affect the chemical and physical morphology of the grain when treated by heating or alkali treatment (Silva et al., 2016). The amylopectin content in starch is easily dispersed in water to form a gel and undergo retrogradation, whereas high amylose content promotes gel formation with a strong retrogradation (Silva et al., 2016). Changes in the morphology of starch granules after processing indicate that alkaline and heat treatments affect the granular structure of the starch. Moreover, high temperatures and alkali treatment can also break down corn grain's strong pericarp and cuticle protein, resulting in increased solubility and increased ruminal degradation (Gonzalez-Rivas et al., 2017). However, data on high-starch energy feeds such as cassava chips and corn grain after heat or alkaline treatments include limited information pertaining to cassava chips. Therefore, this matter remains unknown regarding cassava chips. We hypothesized that various treatment of starch modifications would result in changes in the physical and chemical structures of cassava chips and corn grain and would have diverse effects on ruminal degradation and bypass nutrients. Therefore, our objectives were to investigate the effects of steam, sodium hydroxide $(\mathrm{NaOH})$, and a combination of steam and $\mathrm{NaOH}$ treatments on ruminal degradation and the bypassing of nutrients in two high-starch energy feeds (i.e., corn grain and cassava chips) using an in situ nylon bag technique and an in vitro gas production technique.

\section{MATERIALS AND METHODS}

\section{Animal Ethics}

The experimental procedure was approved by the Animal Ethics Committee of Khon Kaen University based on the Ethics of Animal Experimentation of the National Research Council of Thailand. Record no. ACUC-KKU-64/60.

\section{Experimental Design}

The experiment was designed in a $2 \times 4$ factorial arrangement in a completely randomized design (CRD).
The first factor was high-starch energy feed consisted of two levels, i.e., corn grain and cassava chips, while the second factor was the treating method consisted of 4 levels, i.e., no treatment, steam treatment, $\mathrm{NaOH}$ treatment, and steam with $\mathrm{NaOH}$ treatment. The eight treatment combinations were 1) cassava chips (CV), 2) steamed cassava chips (CVS) 3), $\mathrm{NaOH}$ treated cassava chips (CVN), 4) steamed and $\mathrm{NaOH}$ treated cassava chips (CVSN), 5) corn grain (C), 6) steamed corn grain $(\mathrm{CS}), 7) \mathrm{NaOH}$ treated corn grain $(\mathrm{CN})$, and 8) steamed and $\mathrm{NaOH}$ treated corn grain (CSN).

\section{Sample Preparations}

All corn grain and cassava chips samples were delivered to our laboratory from the animal feed plant, Khon Kaen University, in which the same lot. The method for steam treatment was modified by Domby (2014). The samples of corn grain and dried cassava chips were soaked in water at a ratio of 1:3 (sample: water) for 6 hours (h) to increase moisture content and then steamed at $150^{\circ} \mathrm{C}$ for approximately $45 \mathrm{~min}$ in a steam pot. After that, the steamed corn grain and cassava chips were spread to a carpet for $48 \mathrm{~h}$ in room condition before drying in the oven at $60^{\circ} \mathrm{C}$ for $48 \mathrm{~h}$ and grinding through a 2-mm screen for use as a sample test. The method for $\mathrm{NaOH}$ treatment was prepared by a modified method of Srakaew et al. (2021). The samples of corn grain, dried cassava chips, steamed corn grain, and steamed cassava chips were treated with $3.5 \% \mathrm{NaOH}(35 \mathrm{~g} / \mathrm{kg})$. The $\mathrm{NaOH}$ was applied as a $35 \%$ (wt/vol) solution with water and mixed with the samples for $15 \mathrm{~min}$. Then treated samples and residual $\mathrm{NaOH}$ were loosely packed into one jar per treatment and remained uncovered for $24 \mathrm{~h}$. After a reopened time, the mixed samples were spread to a carpet for $48 \mathrm{~h}$ in room condition before drying in the oven at $60^{\circ} \mathrm{C}$ for $48 \mathrm{~h}$ and then grinding through a 2-mm screen before the test.

\section{Sample Collection and Chemical Analysis}

The samples of corn grain, cassava chips, and all treated samples were dried at $60^{\circ} \mathrm{C}$ for $72 \mathrm{~h}$. The dried samples were grounded over a 1-mm screen for chemical composition analysis. The dry matter (DM) was determined by oven drying at $95^{\circ} \mathrm{C}-100^{\circ} \mathrm{C}$ under pressure $<100 \mathrm{Hg}$ for $5 \mathrm{~h}$ (934.01; AOAC, 2005). Ash content was determined by combustion at $550{ }^{\circ} \mathrm{C}$ for $3 \mathrm{~h}$ in a muffle furnace (942.05; AOAC, 2005). The concentration of nitrogen $(\mathrm{N})$ content was measured using Kjeldahl method (2001.11; AOAC, 2005), and crude protein (CP) content was calculated as $N \times 6.25$. To determine the ether extract (EE), samples were extracted with petroleum ether using FOSS extractor (2003.06; AOAC, 2005). Gross energy (GE) was determined with an adiabatic calorimeter bomb (AC500, LECO Corporation, Michigan-USA). The fiber components were determined by detergent methods, and samples were boiled in neutral detergent plus amylase to determine the neutral detergent fiber (NDF), and boiled in acid detergent to determine the acid detergent fiber (ADF) according to the procedures 
as described by Van Soest et al. (1991). NFC was estimated by different chemical groups (Mertens, 1997) using the following formula:

NFC $(\%)=100-(\mathrm{CP}(\%)+\mathrm{EE}(\%)+\mathrm{NDF}(\%)+$ Ash $(\%))$

\section{DM Disappearance by In Situ Nylon Bag Technique}

Three ruminal fistulated non-lactating Holstein dairy cows (BW $=525 \pm 36.7 \mathrm{~kg}$ ) were used in this experiment. Before the start of the experiment, animals were fed twice daily with a similar diet containing rice straw (60\%) and commercial concentrate (40\%) $(16.0 \% \mathrm{CP}, 10.46 \mathrm{MJ} \mathrm{ME} / \mathrm{kgDM})$ and stayed in $2 \times 5 \mathrm{~m}^{2}$ individual cage inside the evaporative barn. Free water was delivered to the cows by individual nipple cups for 14 days. DM disappearance was determined by using the in situ nylon bag technique according to Ørskov \& McDonald (1979). All samples were oven-dried at $60^{\circ} \mathrm{C}$ for $48 \mathrm{~h}$ and grinding through a $2-\mathrm{mm}$ screen. The whole non-modified or modified samples approximately $4 \mathrm{~g}$ feed sample was taken in pre-weighed nylon bags $(12 \times 6$ $\mathrm{cm}, 38 \mu \mathrm{m}$ average pore size). All nylon bags were tied with nylon threads, fitted to an iron chain, and then suspended in the rumen of three fistulated cows for 2, 4, $8,12,16,24,36$, and $48 \mathrm{~h}$. The samples of each treatment were incubated simultaneously in three animals using triplicates base at each incubation time point. After each incubation time, all bags of each sample test were withdrawn from the rumen and hand-washed in lukewarm water for $10 \mathrm{~min}$ or until wash water was clear. Nylon bags containing mixed test feed residues were then oven-dried at $60^{\circ} \mathrm{C}$ for $48 \mathrm{~h}$ in a forced-air oven. All bags feed samples were collected for their corresponding blanks. The samples at $0 \mathrm{~h}$ of incubation were washed and dried in the oven with a similar condition. After that, DM loss was determined as a different weight before and after incubation.

Bypass of CP and NFC were determined at $16 \mathrm{~h}$ of incubation times (Calsamiglia et al., 1995). Triplicate of mixed residues in nylon bags of each treatment were collected and dried at $60^{\circ} \mathrm{C}$ for $72 \mathrm{~h}$ then analyzed for chemical composition including DM, CP, and NFC. Different CP and NFC contents before and after incubation in the same samples were calculated and used for determining the percentage of CP and NFC degradability and their by-pass from the rumen (Ørskov \& McDonald, 1979).

$\%$ Degradability of nutrients=

(Nutrient in the sample at $16 \mathrm{~h}$ incubation / Nutrient in the sample before incubation) $\times 100$

$\%$ Bypass of nutrients $=100-(\%$ of degradability of nutrient)

Data for ruminal disappearance characteristics of DM was fitted to the exponential equation following the procedure described by Ørskov \& McDonald (1979) and using the NEWAY program.

$\mathrm{P}=\mathrm{a}+\mathrm{b}\left(1-\mathrm{e}^{-\mathrm{ct}}\right)$

where $\mathrm{P}$ was disappearance rate at time $\mathrm{t}(\%)$, a was the intercept of the degradation curve at time zero $(\%), b$ was the fraction of DM which degraded in the rumen $(\%)$, c was a rate constant of the disappearance of fraction $b\left(h^{-1}\right)$, and $t$ was time of incubation $(h)$.

The effective degradability (ED) of DM was, therefore, calculated using the following equation. $\mathrm{ED}=\mathrm{a}+[\mathrm{bc} /(\mathrm{c}+\mathrm{k})]$

where, $\mathrm{k}$ assuming the rate of particulate outflow from the rumen, $\mathrm{k}$, is $0.05 \mathrm{~h}^{-1}$ by the equation of Ørskov \& McDonald (1979).

\section{In Vitro Gas Production}

The in vitro gas production technique was used according to Menke \& Steingass (1988). Rumen fluid was obtained from the same three fistulated non-lactating Holstein dairy cows. Preparation of artificial saliva was conducted by mixing $200 \mathrm{~mL}$ of macro-mineral solution, $0.1 \mathrm{~mL}$ of micro-mineral solution, $200 \mathrm{~mL}$ of buffer solution, and $1 \mathrm{~mL}$ of resazurin solution with $500 \mathrm{~mL}$ of distilled water. $\mathrm{CO}_{2}$ gas was bubbled through the solution until the color change to pink per purple. The $0.4 \mathrm{~g}$ of the air-dried samples were weighed into $50 \mathrm{~mL}$ glass bottle as design at 20 replicate/treatments ( 8 bottles for gas production measurement and 12 bottles for DM degradability test). The bottles were warmed at $39^{\circ} \mathrm{C}$ before the injection of $30 \mathrm{~mL}$ of rumen fluid-buffer mixture (20 mL of artificial saliva and $10 \mathrm{~mL}$ of rumen fluid) into each bottle then incubated in a controlling incubator at $39^{\circ} \mathrm{C}$. During the incubation, the gas production was measured by injecting non-pressure glass syringes into each incubated bottle before reading and recording gas volume showed in the syringes at $1,2,3,4,5,6,7,8,9$, $10,11,12,15,18,21,24,30,36,42$, and 48 h. Cumulative gas production data were fitted to the NEWAY program's model of Ørskov \& McDonald (1979).

$\mathrm{GP}=\mathrm{a}+\mathrm{b}\left(1-\exp ^{(-\mathrm{ct})}\right)$

where a was the gas production from the immediately soluble fraction $(\mathrm{mL}), \mathrm{b}$ was the gas production from the insoluble fraction $(\mathrm{mL}), \mathrm{c}$ was the gas production rate constant for the insoluble fraction (b) $\left(\% \mathrm{~h}^{-1}\right), \mathrm{t}$ was incubation time $(\mathrm{h}),(\mathrm{a}+\mathrm{b})$ was the potential extent of gas production $(\mathrm{mL})$, and GP was gas produced at time " $\mathrm{t}$ " (mL).

The effective gas production (EP) was, therefore, calculated using the following equation.

$\mathrm{EP}=\mathrm{a}+[\mathrm{bc} /(\mathrm{c}+\mathrm{k})]$

where, $\mathrm{k}$ assuming the rate of particulate outflow from the rumen, $\mathrm{k}$, is $0.05 \mathrm{~h}^{-1}$ by the equation of Ørskov \& McDonald (1979).

\section{Statistical Analysis}

All obtained data were subjected to the analysis of variance (ANOVA) procedures of SAS (1998) according to a $2 \times 4$ factorial arrangement in CRD. Treatment means were compared using Duncan's New Multiple Range Test (Steel \& Torrie, 1980). Mean differences were considered significant at $p<0.05$. Standard errors of means were calculated from the residual mean square in the 
analysis of variance. The relationships between in situ and in vitro gas production parameters were obtained by simple linear regression analysis. The statistical model was:

$\mathrm{Y}_{\mathrm{ijk}}=\mu+\alpha_{\mathrm{i}}+\beta_{\mathrm{j}}+\alpha \beta_{\mathrm{k}}+\mathrm{e}_{\mathrm{ijk}}$

where $Y_{i j k}$ was observation in treatment combination ij and replicated $j, \mu$ was over-all sample means, $\alpha_{i \text { was }}$ effect of factor $A, \beta$, was effect of factor $B, \alpha \beta_{i}$ was effect of interaction $A B$, and $e_{i j \mathrm{k}}$ was error associated with observation.

\section{RESULTS}

\section{Chemical Composition}

The chemical compositions of untreated and treated corn grain and cassava chips are presented in Table 1. Gross energy and ash were not significantly different among treatment combinations, high-starch energy feeds, and treating methods. For CP, EE, and NFC, a significant interaction $(\mathrm{p}<0.01)$ was detected between highstarch energy feed sources and treating methods. The NDF and ADF contents were influenced by high-starch energy feeds, which were higher $(p<0.01)$ in untreated and treated corn grain than in untreated and treated cassava chips but were not influenced by treatment methods. The results showed that untreated and treated corn grains had higher CP and EE contents $(p<0.01)$ than untreated and treated cassava chips. Although treating methods reduced $\mathrm{CP}$ and EE in both high-starch energy feeds, the reduction was not significant. CP and EE contents in corn grain and cassava chips were decreased $(p<0.05)$ after steam and $\mathrm{NaOH}$ treatments. Untreated corn grain had a lower NFC content than steam cassava chip $(p<0.01)$. On the other hand, differences in treatment methods had no effect on NFC content.

\section{In Situ DM Degradability}

Degradability patterns are presented in Figure 1. The results indicated that the overall mean of untreated and treated cassava chips underwent higher degradation $(\mathrm{p}<0.01)$ than untreated and treated corn grain (Figure 1B). At 0 to $48 \mathrm{~h}$ of incubation, the DM disappearance of cassava chips decreased for all treatment methods $(p<0.01)$ (Figure $1 C)$. By contrast, the results for corn grain showed that all treating methods increased DM degradation $(\mathrm{p}<0.01)$ (Figure 1D).

\section{In Situ Degradation Characteristics}

The effect of treatment methods and high-starch energy sources on the rapidly soluble fraction ( $a_{i s}$ fraction), potentially degradable fraction $\left(b_{i s}\right.$ fraction), rate of degradation of $b$ fraction $\left(c_{i s}\right)$, and effective degradability potential $\left(\mathrm{ED}_{\mathrm{is}}\right)$ are presented in Table 2. A significant interaction of high-starch energy feed sources and treating methods were observed for $b_{i s^{\prime}} c_{i s^{\prime}}$ and $\mathrm{ED}_{\text {is }}$ $(\mathrm{p}<0.01)$ and $a_{i s}(\mathrm{p}<0.05)$. Treatment's main effects on in situ degradation characteristics were largely explained by differences of $a_{i s^{\prime}} b_{i s^{\prime}} c_{i s^{\prime}}$ and ED . Fractions of $a_{i s^{\prime}} c_{i s^{\prime}}$ and $\mathrm{ED}_{\text {is }}$ for cassava chips were higher $(\mathrm{p}<0.01)$, but the $\mathrm{b}_{i \mathrm{~s}}$ fraction was lower $(\mathrm{p}=0.07)$ than that of corn grain. In terms of treatment methods, all treated cassava chips (CVS, CVN, and CVSN) showed a decrease $(p<0.01)$ in $a_{i s}$ and $\mathrm{ED}_{\text {is }}$ fractions compared with untreated cassava chips $(\mathrm{CV})$, whereas the fraction of $b$ is increased significantly $(\mathrm{p}<0.01)$ after treatment. Treatment methods of corn grain in the CS, CN, and CSN groups did not significantly affect $(\mathrm{p}>0.05)$ the $a_{i s}$ and $c_{i s}$ fractions. However, treating methods led to the increased $b_{\text {is }}$ and $\mathrm{ED}_{\text {is }}$ fractions.

Table 1. Chemical composition of high-starch energy feeds (cassava chips and corn grain) with treating methods

\begin{tabular}{|c|c|c|c|c|c|c|c|c|}
\hline \multirow{2}{*}{ Items } & \multirow{2}{*}{ DM \% } & $\mathrm{CP}$ & $\mathrm{EE}$ & Ash & NDF & $\mathrm{ADF}$ & NFC & \multirow{2}{*}{ GE kcal/kgDM } \\
\hline & & \multicolumn{6}{|c|}{$\%$ on DM basis } & \\
\hline \multicolumn{9}{|l|}{ Treatments } \\
\hline $\mathrm{CV}$ & 90.40 & $2.27 \pm 0.30^{\mathrm{b}}$ & $1.02 \pm 0.03^{\mathrm{b}}$ & $5.58 \pm 0.00$ & $14.410 .086^{\mathrm{a}}$ & $6.50 \pm 0.49^{a}$ & $76.71 \pm 0.41^{\mathrm{ab}}$ & $3,713.02 \pm 10.59$ \\
\hline CVS & 90.10 & $1.71 \pm 0.03^{b}$ & $0.73 \pm 0.04^{b}$ & $4.99 \pm 0.01$ & $14.89 \pm 0.62^{\mathrm{a}}$ & $6.30 \pm 0.35^{\mathrm{a}}$ & $77.62 \pm 0.51^{\mathrm{a}}$ & $3,746.04 \pm 0.03$ \\
\hline CVN & 89.70 & $1.61 \pm 0.04^{b}$ & $0.67 \pm 0.10^{\mathrm{b}}$ & $6.64 \pm 0.04$ & $14.62 \pm 0.11^{\mathrm{a}}$ & $6.44 \pm 0.16^{\mathrm{a}}$ & $76.38 \pm 0.28^{\mathrm{ab}}$ & $3,543.02 \pm 0.40$ \\
\hline CVSN & 90.20 & $1.51 \pm 0.04^{\mathrm{b}}$ & $0.78 \pm 0.05^{b}$ & $6.26 \pm 0.08$ & $15.81 \pm 0.04^{\mathrm{a}}$ & $6.28 \pm 0.04^{a}$ & $75.57 \pm 0.25^{\mathrm{ab}}$ & $3,527.01 \pm 2.88$ \\
\hline $\mathrm{C}$ & 90.60 & $8.44 \pm 0.35^{\mathrm{a}}$ & $4.95 \pm 0.17^{a}$ & $4.62 \pm 0.07$ & $10.98 \pm 0.07^{b}$ & $3.74 \pm 0.06^{b}$ & $70.89 \pm 0.03^{b}$ & $3,700.03 \pm 12.95$ \\
\hline $\mathrm{CS}$ & 89.90 & $7.85 \pm 0.36^{\mathrm{a}}$ & $4.35 \pm 0.07^{a}$ & $4.74 \pm 0.06$ & $10.80 \pm 0.19^{b}$ & $4.06 \pm 0.19^{b}$ & $72.28 \pm 0.80^{\mathrm{ab}}$ & $3,911.04 \pm 5.90$ \\
\hline $\mathrm{CN}$ & 90.10 & $7.61 \pm 0.27^{a}$ & $3.68 \pm 0.03^{a}$ & $5.61 \pm 0.99$ & $10.11 \pm 0.65^{\mathrm{b}}$ & $4.54 \pm 0.25^{b}$ & $73.02 \pm 0.64^{\mathrm{ab}}$ & $3,884.01 \pm 4.02$ \\
\hline CSN & 90.00 & $7.67 \pm 0.47^{a}$ & $4.45 \pm 0.22^{\mathrm{a}}$ & $5.07 \pm 0.00$ & $10.39 \pm 0.55^{\mathrm{b}}$ & $4.15 \pm 0.22^{b}$ & $72.42 \pm 0.60^{\mathrm{ab}}$ & $3,767.02 \pm 14.40$ \\
\hline SEM & - & 1.203 & 0.779 & 1.203 & 1.628 & 0.816 & 2.028 & 152.004 \\
\hline \multicolumn{9}{|c|}{ Comparison, P-value } \\
\hline \multicolumn{2}{|c|}{ High-starch energy feeds } & $<0.01$ & $<0.01$ & 0.26 & $<0.01$ & $<0.01$ & $<0.01$ & 0.42 \\
\hline \multicolumn{2}{|c|}{ Treating methods } & 0.05 & 0.01 & 0.10 & 0.24 & 0.77 & 0.69 & 0.53 \\
\hline \multicolumn{2}{|c|}{ Interaction } & $<0.01$ & $<0.01$ & 0.18 & $<0.01$ & $<0.01$ & $<0.01$ & 0.28 \\
\hline
\end{tabular}

Note: Means in the same column with different superscripts differ significantly $(\mathrm{p}<0.05)$. $\mathrm{SEM}=$ standard error of means; $\mathrm{DM}=\mathrm{dry}$ matter; $\mathrm{CP}=\mathrm{crude}$ protein; $\mathrm{EE}=$ ether extract; $\mathrm{NDF}=$ neutral detergent fiber; $\mathrm{ADF}=$ acid detergent fiber; $\mathrm{NFC}=$ non-fiber carbohydrate; $\mathrm{GE}=$ gross energi; $\mathrm{CV}=$ untreated cassava chips; $\mathrm{CVS}=$ steamed cassava chips; $\mathrm{CVN}=\mathrm{NaOH}$ treated cassava chips; $\mathrm{CVSN}=$ steamed and $\mathrm{NaOH}$ treated cassava chips; $\mathrm{C}=$ untreated corn grain; $\mathrm{CS}=$ steamed corn grain; $\mathrm{CN}=\mathrm{NaOH}$ treated corn grain; $\mathrm{CSN}=$ steamed and $\mathrm{NaOH}$ treated corn grain . 


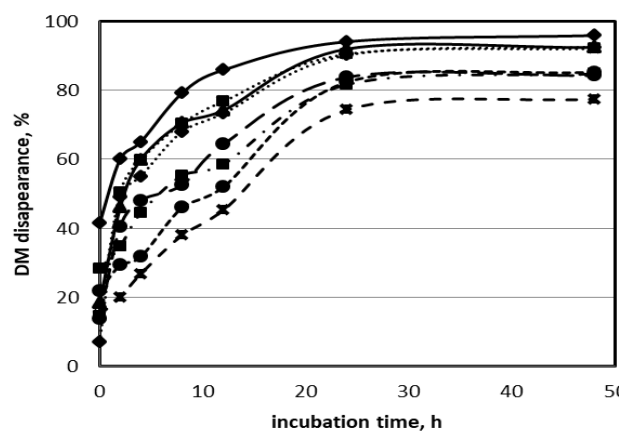

$1 \mathrm{~A}$

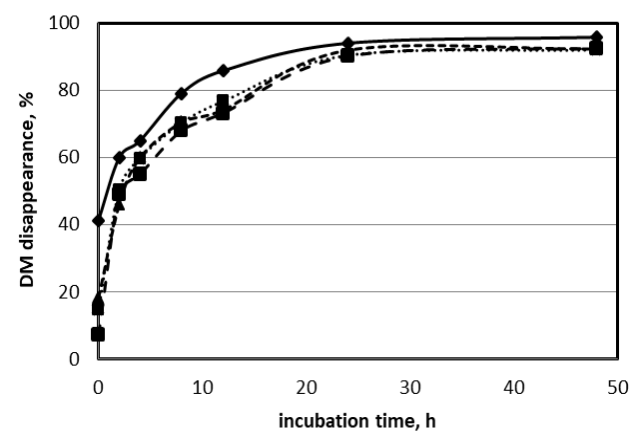

$1 \mathrm{C}$

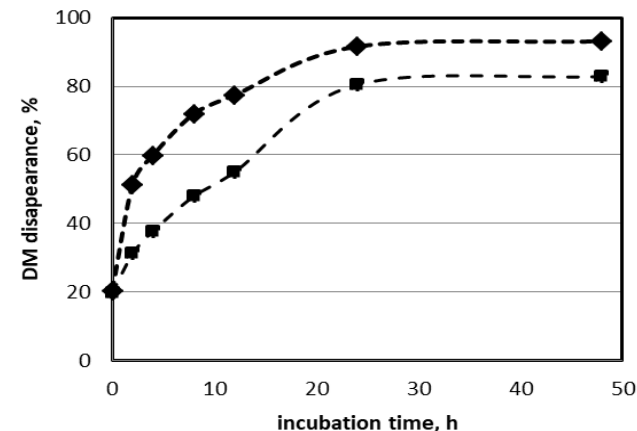

1B

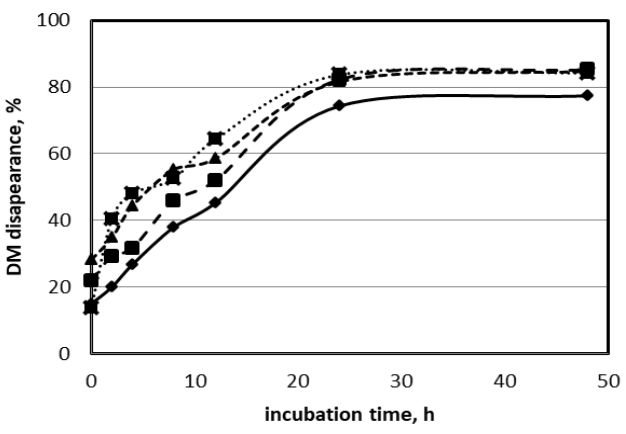

1D

Figure 1. In situ DM disappearance of treatment combinations between the high-starch energy feeds and treating methods $(1 \mathrm{~A} ; \rightarrow=$

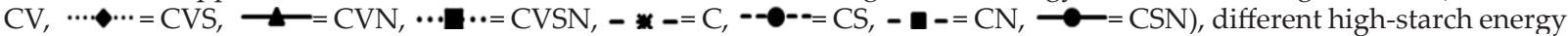

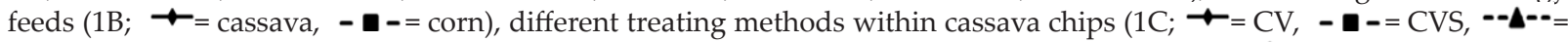

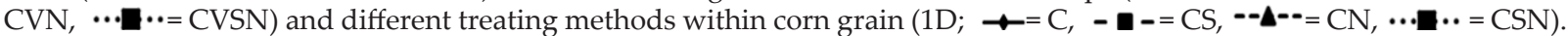
$\mathrm{CV}=$ untreated cassava chips; $\mathrm{CVS}=$ steamed cassava chips; $\mathrm{CVN}=\mathrm{NaOH}$ treated cassava chips; $\mathrm{CVSN}=$ steamed and $\mathrm{NaOH}$ treated cassava chips; $\mathrm{C}=$ untreated corn grain; $\mathrm{CS}=$ steamed corn grain; $\mathrm{CN}=\mathrm{NaOH}$ treated corn grain; $\mathrm{CSN}=$ steamed and $\mathrm{NaOH}$ treated corn grain.

Table 2. In situ degradation characteristics of high-starch energy feeds (cassava chips and corn grain) with treating methods

\begin{tabular}{|c|c|c|c|c|}
\hline \multirow{2}{*}{ Items } & \multicolumn{3}{|c|}{ In situ degradation characteristics } & \multirow{2}{*}{$\begin{array}{c}\text { Effective } \mathrm{DM} \\
\text { degradability }\left(\mathrm{ED}_{\mathrm{is}}\right), \%\end{array}$} \\
\hline & $a_{i s^{\prime}} \%$ & $b_{i s^{\prime}} \%$ & $c_{i s^{\prime}} \% \mathrm{~h}^{-1}$ & \\
\hline \multicolumn{5}{|l|}{ Treatments } \\
\hline $\mathrm{CV}$ & $42.00 \pm 2.00^{\mathrm{a}}$ & $52.60 \pm 1.14^{c}$ & $0.140 \pm 0.01^{\mathrm{b}}$ & $52.10 \pm 3.55^{a}$ \\
\hline CVS & $13.70 \pm 1.70^{\mathrm{b}}$ & $69.60 \pm 8.32^{\mathrm{b}}$ & $0.210 \pm 0.01^{\mathrm{a}}$ & $31.40 \pm 8.66^{\mathrm{bc}}$ \\
\hline $\mathrm{CVN}$ & $21.10 \pm 2.43^{\mathrm{b}}$ & $67.00 \pm 4.00^{\mathrm{b}}$ & $0.260 \pm 0.01^{\mathrm{a}}$ & $41.50 \pm 6.17^{b}$ \\
\hline CVSN & $17.70 \pm 0.17^{\mathrm{b}}$ & $66.70 \pm 6.66^{\mathrm{b}}$ & $0.250 \pm 0.02^{\mathrm{a}}$ & $37.30 \pm 6.44^{\mathrm{b}}$ \\
\hline $\mathrm{C}$ & $18.50 \pm 2.00^{\mathrm{b}}$ & $64.10 \pm 1.14^{\mathrm{b}}$ & $0.040 \pm 0.01^{\mathrm{c}}$ & $22.30 \pm 6.73^{c}$ \\
\hline CS & $19.90 \pm 1.70^{\mathrm{b}}$ & $79.40 \pm 8.32^{\mathrm{a}}$ & $0.030 \pm 0.01^{\mathrm{c}}$ & $34.60 \pm 7.88^{\mathrm{b}}$ \\
\hline $\mathrm{CN}$ & $28.90 \pm 2.43^{\mathrm{b}}$ & $76.70 \pm 4.00^{\mathrm{a}}$ & $0.050 \pm 0.01^{\mathrm{c}}$ & $30.10 \pm 8.88^{\mathrm{bc}}$ \\
\hline CSN & $20.20 \pm 0.17^{b}$ & $65.90 \pm 6.66^{b}$ & $0.080 \pm 0.02^{c}$ & $26.20 \pm 7.38^{\mathrm{bc}}$ \\
\hline SEM & 2.438 & 2.747 & 0.010 & 2.143 \\
\hline \multicolumn{5}{|l|}{ Comparison, $\mathrm{P}$-value } \\
\hline High-starch energy feeds & 0.74 & 0.07 & $<0.01$ & 0.01 \\
\hline Treating methods & 0.03 & 0.98 & $<0.01$ & $<0.01$ \\
\hline Interaction & 0.02 & 0.01 & $<0.01$ & $<0.01$ \\
\hline
\end{tabular}

Note: Means in the same column with different superscripts differ significantly $(\mathrm{p}<0.05)$. SEM= standard error of means; $a_{i s}=$ the intercept of the degradation curve at time zero; $b=$ the fraction of $\mathrm{DM}$ which degraded in the rumen; $c=\mathrm{a}$ rate constant of the disappearance of fraction $\mathrm{b}$; $\mathrm{CV}=$ untreated cassava chips; $\mathrm{CVS}=$ steamed cassava chips; $\mathrm{CVN}=\mathrm{NaOH}$ treated cassava chips; $\mathrm{CVSN}=$ steamed and $\mathrm{NaOH}$ treated cassava chips; $\mathrm{C}=$ untreated corn grain; $\mathrm{CS}=$ steamed corn grain; $\mathrm{CN}=\mathrm{NaOH}$ treated corn grain; $\mathrm{CSN}=$ steamed and $\mathrm{NaOH}$ treated corn grain.

\section{In Situ Ruminal Bypass CP and NFC}

Degradable CP and NFC, bypass CP, and bypass NFC were calculated and are presented in Table 3. There was a significant interaction between main effects $(\mathrm{p}<0.01)$ in ruminal degradability and bypass of $\mathrm{CP}$ and NFC. The main effects were originally evaluated. The data showed that cassava chips underwent higher $\mathrm{CP}$ and NFC degradation in the rumen than corn grain did, leading to lower $(\mathrm{p}<0.01)$ bypass $\mathrm{CP}$ and NFC flow 
from the rumen to the lower gut. Steam and $\mathrm{NaOH}$ treatments changed the physical form of cassava chips and corn grain. Enhanced degradability of CP and NFC was found in treated corn grain (CS, CN, and CSN), but treated cassava chips (CVS, CVN, and CVSN) showed significant decreases $(p<0.01)$ when compared with untreated high-starch energy feeds. Bypass CP and NFC increased significantly in treated cassava chips (CVS, CVN, and CVSN), whereas no differences were shown in treated corn. Treated corn grain (CS, CN, and CSN) had lower $(\mathrm{p}<0.05)$ bypass NFC than did untreated corn grain $(\mathrm{C})$.

\section{In Vitro Gas Production Characteristics}

Patterns of in vitro gas production characteristics for various treating methods and high-starch energy feeds are presented in Table 4 and Figure 2. A significant interaction of main effects was observed for $c_{\text {qas }}$ and ED $(\mathrm{p}<0.01)$ but $a_{i s}$ and $b_{i s}$ were not influenced $(\mathrm{p}>0.05)$ by high-starch energy feeds and treating methods interaction. For high-starch energy feeds, cumulative gas production over $48 \mathrm{~h}$, rate of gas production $\left(c_{g a s}\right)$, and effective gas production potential $\left(\mathrm{EP}_{\mathrm{gas}}\right)$ of cassava chips were higher $(p<0.01)$ than those of corn grain (Table

Table 3. Ruminal bypass crude protein (CP) and non-fiber carbohydrate (NFC) of treatment combinations between the high-starch energy feeds (cassava chips and corn grain) and treating methods

\begin{tabular}{|c|c|c|c|c|}
\hline \multirow{2}{*}{ Items } & \multicolumn{2}{|c|}{ Ruminal degradability, \% } & \multicolumn{2}{|c|}{ Ruminal bypass, $\%$} \\
\hline & $\mathrm{CP}$ & NFC & $\mathrm{CP}$ & NFC \\
\hline \multicolumn{5}{|l|}{ Treatments } \\
\hline $\mathrm{CV}$ & $82.72 \pm 0.57^{a}$ & $95.40 \pm 0.42^{\mathrm{a}}$ & $17.32 \pm 0.57^{c}$ & $4.60 \pm 0.42^{c}$ \\
\hline CVS & $73.74 \pm 0.85^{\mathrm{b}}$ & $88.59 \pm 0.85^{b}$ & $26.31 \pm 0.85^{\mathrm{bc}}$ & $11.41 \pm 0.85^{\mathrm{b}}$ \\
\hline CVN & $70.41 \pm 0.57^{\mathrm{b}}$ & $88.12 \pm 1.13^{\mathrm{b}}$ & $29.63 \pm 0.57 b$ & $11.88 \pm 1.13^{\mathrm{b}}$ \\
\hline CVSN & $70.66 \pm 0.28^{\mathrm{b}}$ & $88.35 \pm 1.84^{b}$ & $29.45 \pm 0.28^{b}$ & $11.65 \pm 1.84^{\mathrm{b}}$ \\
\hline $\mathrm{C}$ & $55.24 \pm 0.99^{d}$ & $84.40 \pm 1.13^{\mathrm{b}}$ & $44.80 \pm 0.99^{a}$ & $15.60 \pm 1.13^{a}$ \\
\hline CS & $61.19 \pm 0.99^{c}$ & $86.20 \pm 0.71^{b}$ & $38.95 \pm 0.99^{a}$ & $13.80 \pm 0.71^{\mathrm{ab}}$ \\
\hline $\mathrm{CN}$ & $60.72 \pm 1.70^{c}$ & $87.36 \pm 0.03^{b}$ & $39.36 \pm 1.70^{a}$ & $12.44 \pm 0.03^{\mathrm{b}}$ \\
\hline CSN & $61.33 \pm 0.42^{c}$ & $87.72 \pm 0.28^{b}$ & $38.74 \pm 0.42^{\mathrm{a}}$ & $12.28 \pm 0.28^{\mathrm{b}}$ \\
\hline SEM & 1.760 & 1.892 & 2.950 & 1.728 \\
\hline \multicolumn{5}{|l|}{ Comparison, $\mathrm{P}$-value } \\
\hline High-starch energy feeds & $<0.01$ & 0.19 & $<001$ & $<001$ \\
\hline Treating methods & 2.33 & 3.58 & 0.05 & 0.23 \\
\hline Interaction & 0.01 & 0.01 & 0.01 & 0.01 \\
\hline
\end{tabular}

Note: Means in the same column with different superscripts differ significantly $(\mathrm{p}<0.05)$. $\mathrm{SEM}=$ standard error of means; $\mathrm{CP}=$ crude protein; $\mathrm{NFC}=$ nonfiber carbohydrate; $\mathrm{CV}=$ untreated cassava chips; $\mathrm{CVS}=$ steamed cassava chips; $\mathrm{CVN}=\mathrm{NaOH}$ treated cassava chips; $\mathrm{CVSN}=$ steamed and $\mathrm{NaOH}$ treated cassava chips; $\mathrm{C}=$ untreated corn grain; $\mathrm{CS}=$ steamed corn grain; $\mathrm{CN}=\mathrm{NaOH}$ treated corn grain; $\mathrm{CSN}=$ steamed and $\mathrm{NaOH}$ treated corn grain.

Table 4. In vitro gas production characteristics of high-starch energy feeds (cassava chips and corn grain) with treating methods

\begin{tabular}{|c|c|c|c|c|}
\hline \multirow{2}{*}{ Items } & \multicolumn{3}{|c|}{ In vitro gas production characteristics } & \multirow{2}{*}{$\begin{array}{c}\text { Effective gas } \\
\text { production }\left(\mathrm{EP}_{\mathrm{gas}}\right), \%\end{array}$} \\
\hline & $a_{g a s^{\prime}} \%$ & $b_{g a s^{\prime}} \%$ & $c_{g a s^{\prime}} \% h^{-1}$ & \\
\hline \multicolumn{5}{|l|}{ Treatments } \\
\hline $\mathrm{CV}$ & $-7.85 \pm 0.35$ & $72.60 \pm 2.51$ & $0.120 \pm 0.023^{\mathrm{a}}$ & $48.50 \pm 4.62$ \\
\hline CVS & $-5.35 \pm 0.11$ & $64.00 \pm 2.79$ & $0.080 \pm 0.002^{\mathrm{b}}$ & $40.10 \pm 2.05$ \\
\hline $\mathrm{CVN}$ & $-5.14 \pm 0.06$ & $64.90 \pm 2.53$ & $0.110 \pm 0.006^{\mathrm{b}}$ & $44.40 \pm 2.34$ \\
\hline CVSN & $-5.38 \pm 0.24$ & $67.20 \pm 1.54$ & $0.100 \pm 0.014^{\mathrm{b}}$ & $44.20 \pm 2.67$ \\
\hline $\mathrm{C}$ & $-5.87 \pm 0.34$ & $54.60 \pm 0.39$ & $0.070 \pm 0.001^{\mathrm{b}}$ & $34.20 \pm 0.03$ \\
\hline CS & $-6.02 \pm 0.07$ & $64.30 \pm 1.83$ & $0.070 \pm 0.002^{\mathrm{b}}$ & $39.20 \pm 0.98$ \\
\hline $\mathrm{CN}$ & $-6.05 \pm 0.07$ & $70.70 \pm 1.13$ & $0.070 \pm 0.000^{\mathrm{b}}$ & $39.40 \pm 0.65$ \\
\hline CSN & $-5.95 \pm 0.11$ & $63.40 \pm 0.87$ & $0.100 \pm 0.005^{\mathrm{b}}$ & $42.20 \pm 0.79$ \\
\hline SEM & 0.36 & 0.26 & 0.010 & 4.323 \\
\hline \multicolumn{5}{|l|}{ Comparison, $\mathrm{P}$-value } \\
\hline High-starch energy feeds & 0.62 & 0.68 & 0.01 & $<0.01$ \\
\hline Treating methods & 0.42 & 0.42 & 0.53 & 0.21 \\
\hline Interaction & 0.36 & 0.26 & 0.01 & 0.11 \\
\hline
\end{tabular}

Note: Means in the same column with different superscripts differ significantly $(\mathrm{p}<0.05)$. SEM= standard error of means; $a_{\text {gas }}=$ the gas production from the immediately soluble fraction; $b_{g a s}=$ the gas production from the insoluble fraction; $c_{\text {ogs }}=$ the gas production rate constant for the insoluble fraction (b); $\mathrm{CV}=$ untreated cassava chips; $\mathrm{CVS}=$ steamed cassava chips; $\mathrm{CVN}=\mathrm{NaOH}$ treated cassava chips; $\mathrm{CVSN}=$ steamed and $\mathrm{NaOH}$ treated cassava chips; $\mathrm{C}=$ untreated corn grain; $\mathrm{CS}=$ steamed corn grain; $\mathrm{CN}=\mathrm{NaOH}$ treated corn grain; $\mathrm{CSN}=$ steamed and $\mathrm{NaOH}$ treated corn grain. 


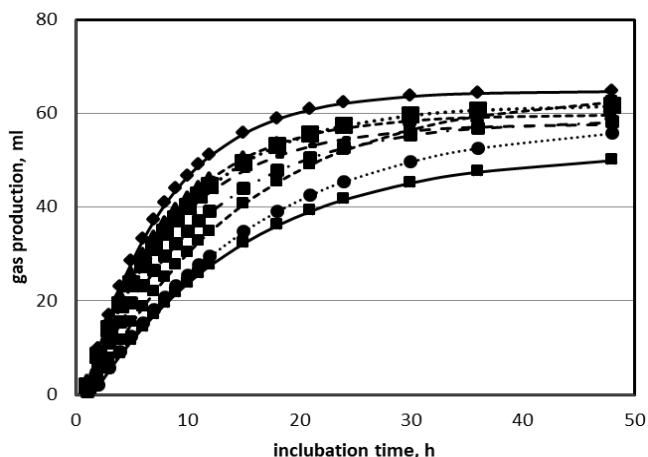

2A

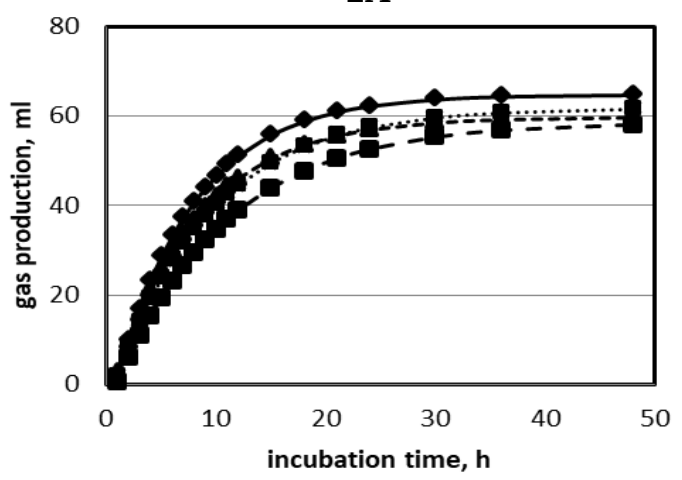

$2 \mathrm{C}$

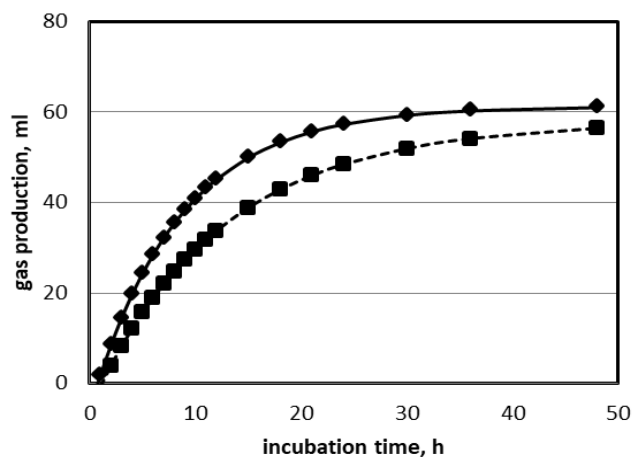

2B

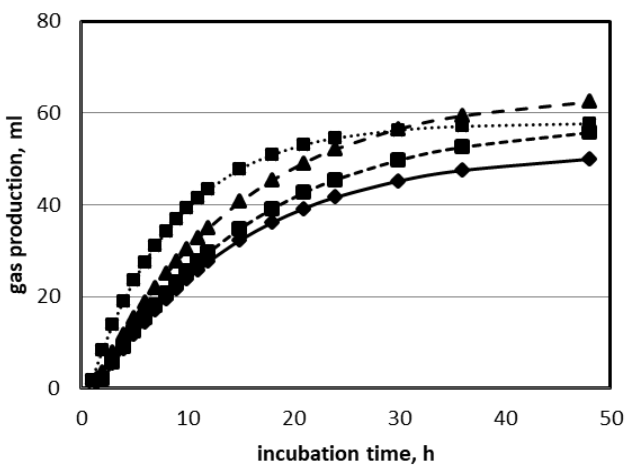

2D

Figure 2. Cumulative gas production incubated with rumen fluid for treatment combinations between the treating methods and high-

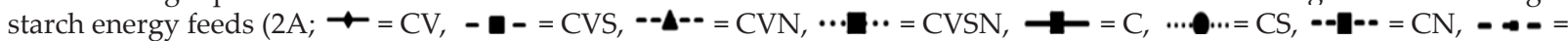

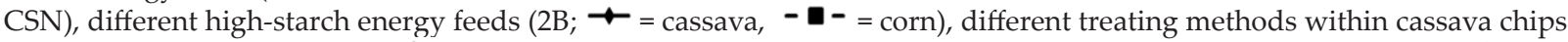

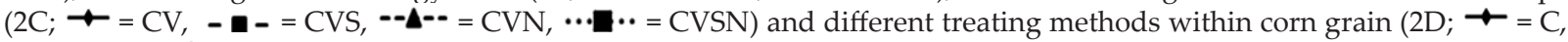

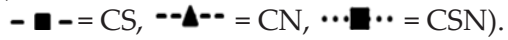

$\mathrm{CV}=$ untreated cassava chips; $\mathrm{CVS}=$ steamed cassava chips; $\mathrm{CVN}=\mathrm{NaOH}$ treated cassava chips; $\mathrm{CVSN}=$ steamed and $\mathrm{NaOH}$ treated cassava chips; $\mathrm{C}=$ untreated corn grain; $\mathrm{CS}=$ steamed corn grain; $\mathrm{CN}=\mathrm{NaOH}$ treated corn grain; $\mathrm{CSN}=$ steamed and $\mathrm{NaOH}$ treated corn grain.

4). The treated cassava chips (CVS, CVN, and CVSN) produced less gas during early incubation until after 12 h. Gas productions in the treated cassava chips (CVS, CVN, and CVSN) increased in the same manner, and the extent of gas production was similar but remained low $(\mathrm{p}<0.01)$ compared with the untreated cassava chips $(\mathrm{CV})$. The $\mathrm{EP}_{\text {gas }}$ fraction decreased $(\mathrm{p}<0.05)$ in the CVS, CVN, and CVSN groups compared with CV. This result concurred with the degradability trial using the in situ nylon bag technique, which showed significantly decreased $\mathrm{ED}_{\text {is }}$ in treated cassava chips than untreated cassava chips. In terms of corn grain, treating methods affected $(p<0.05)$ accumulated gas production, with higher gas production found in treated corn grain (CS, CN, and CSN groups) as compared with the untreated corn grain (C group). $\mathrm{EP}_{\text {gas }}$ fractions were higher $(\mathrm{p}<0.01)$ for the $\mathrm{CS}, \mathrm{CN}$, and CSN groups than for the $\mathrm{C}$ group.

\section{Regression Equation}

Apparent DMD using in situ nylon bag technique (Figure 1) and gas production using in vitro gas production technique (Figure 2) produced similar results. As can be seen from Table 5, in vitro gas production characteristics from the fraction of $a_{\text {gas }} b_{\text {gas }}$ and $\mathrm{EP}$ gas explained $90.61 \%, 93.83 \%$, and $91.99 \%$ of the variations of $a_{i s^{\prime}} b_{i s^{\prime}}$ and $\mathrm{ED}_{\text {is }}$ in cassava chips. In situ nylon bag characteristics from the fraction of $a_{g a s^{\prime}} b_{g a s^{\prime}} c_{\text {gas }}$ and $\mathrm{EP}_{\text {gas }}$ explained $23.36 \%, 50.92 \%, 98.45 \%$, and $89.74 \%$ of the variations of $a_{i s^{\prime}} c_{i s^{\prime}}$ and $\mathrm{ED}_{\text {is }}$ in corn grain.

\section{DISCUSSION}

Chemical compositions of cassava chips and corn grain have been altered by treatment methods. Crude protein and EE contents in untreated corn grain and treated corn grain were higher than in untreated cassava chips and treated cassava chips. The average range of $\mathrm{CP}$ and EE in corn grain (7.61-8.44, 3.68-4.95) and cassava chips $(1.51-2.27,0.67-1.02)$ were similar to many previous studies that reported cassava chips and corn grain as high-starch energy source feeds, with cassava chips containing $2.3 \% \mathrm{CP}$ and $0.3 \% \mathrm{EE}$ and corn grain containing $8.8 \% \mathrm{CP}$ and $4.7 \% \mathrm{EE}$ (Suksombat et al., 2007). The reduction of $\mathrm{CP}$ and $\mathrm{EE}$ contents in all treated cassava chips and corn grain in this experiment were similar to the findings of Ma et al. (2019), who found that, after steaming, the bulk density of normal corn grain and the $\mathrm{CP}$ and EE concentrations decreased. This occurred because a higher-temperature treatment at $100{ }^{\circ} \mathrm{C}$ reduced the $\mathrm{CP}$ and EE concentrations. Similar results were reported by Bhuiyan et al. (2012), who observed a reduc- 
Table 5. Prediction of in situ nylon bag characteristics and estimated parameters from in vitro gas production

\begin{tabular}{|c|c|c|c|c|}
\hline Items & Equation and factors use & $\mathrm{R}^{2}$ & RSD & Sig. \\
\hline \multicolumn{5}{|l|}{ Cassava chips (CV) } \\
\hline$a_{i s c v}$ & $Y=-9.368_{\text {agasco }}-31.971$ & 90.61 & 4.743 & * \\
\hline$b_{i s c v}$ & $\mathrm{Y}=-1.935_{\text {bgascv }}^{\circ}+193.92$ & 93.83 & 2.345 & * \\
\hline$c_{i s c v}$ & $\mathrm{Y}=-0.960_{\text {cgascv }}+0.331$ & 9.94 & 0.063 & ns \\
\hline $\mathrm{ED}_{\text {iscv }}$ & $\mathrm{Y}=1.385 \mathrm{EP}_{\text {gasco }}+16.190$ & 91.99 & 0.569 & * \\
\hline \multicolumn{5}{|l|}{ Corn grain $(\mathrm{C})$} \\
\hline$a_{i s c}$ & $Y=-10.482_{\text {agasc }}-39.706$ & 23.36 & 5.122 & ns \\
\hline$b_{i s c}$ & $\mathrm{Y}=1.018_{\text {bgasc }}+6.339$ & 50.92 & 6.568 & ns \\
\hline$c_{i s c}$ & $\mathrm{Y}=1.298_{\text {cgasc }}-0.052$ & 98.45 & 0.005 & $* *$ \\
\hline $\mathrm{ED}_{\mathrm{isc}}$ & $\mathrm{Y}=1.869 \mathrm{EP}_{\text {gasc }}-8.488$ & 89.74 & 3.885 & * \\
\hline \multicolumn{5}{|c|}{ Combined high energy starch sources } \\
\hline $\mathrm{ED}_{\text {is }}$ & $\mathrm{Y}=2.108 \mathrm{EP}_{g a s}-15.108$ & 93.24 & 3.541 & $* *$ \\
\hline
\end{tabular}

Note: $\mathrm{ns}=$ non-significant different $(\mathrm{p}>0.05) ;{ }^{*}=\mathrm{p}<0.05 ;{ }^{* *}=\mathrm{p}<0.01 ; \mathrm{RSD}=$ residual standard deviation; Sig.= significant level; $a_{\mathrm{is}}=$ the intercept of the degradation curve at time zero; $b=$ the fraction of $\mathrm{DM}$ which degraded in the rumen; $c_{i}=$ a rate constant of the disappearance of fraction $\mathrm{b} ; a=$ the gas production from the immediately soluble fraction; $b_{\text {gas }}=$ the gas production from the insoluble fraction; $c_{\text {gas }}=$ the gas production rate constant for the insoluble fraction (b); $\mathrm{EP}_{\text {gas }}=$ effective gas production potential.

tion in EE and energy contents in corn grain because of high temperatures. The thermo-alkaline process of the $\mathrm{NaOH}$ treatment drastically changed the appearance in some areas of the grain kernels (e.g., protein, lipids, and the principal component as starch). Therefore, the alkaline steeping method produced low protein, lipid, and starch (Palacios-Fonseca et al., 2013).

Because NFC is composed of starch, simple sugars, and soluble fiber, NRC (2001) reported that the starch content of certain feeds such as corn grain and barley ranged between $80.0 \%$ and $81.7 \%$ of NFC. Moreover, other researchers reported that whole corn contains high starch content $(79.0 \%)$ (Perez-Carrillo et al., 2011), whereas cassava chips contain less starch (69.7\%) (Nitayavardhana et al., 2010). It can therefore be assumed that the NFC in corn grain and cassava chips consists mainly of starch. Our experimental results showed that the NFC content in cassava chips ranged from $75.6 \%$ to $77.6 \%$, higher than corn grain, which ranged from $70.9 \%$ to $73.0 \%$. However, previous studies reported similar NFC content in ground corn $(73.0 \%$ $73.4 \%$ ) (Fernandes et al., 2015) but lower NFC content in cassava chips (69.7\%) (Suksombat et al., 2007).

The DMD of cassava chips was higher than that of corn grain. Sommart et al. (2000) reported that the rate of ruminal DM degradation from cassava chips was higher than corn grain, whereas Huntington (1997) mentioned that ruminal degradable starch values following the in situ method for corn grain, wheat, and cassava chips were $49.5 \%, 88.3 \%$, and $94.0 \%$, respectively. The ruminal degradability of starch varies depending on the grain source. For example, barley, cassava, and wheat starch have high solubility with a slower rate of degradable protein matrix in their endosperms than corn starch (Moharrery et al., 2014). Dry and ground corn tend to have a lower digestibility than other grains because of the resistance of their seed coat to digestion and less surface area per unit weight in grains with larger kernels (Gonzalez-Rivas et al., 2017).

The DMD of cassava chips decreased for all treatment methods, whereas corn grain's disappearance in- creased in all treatment methods. These results indicate that steam and $\mathrm{NaOH}$ treatment methods negatively affected ruminal degradation in cassava chips but positively affected corn grain. These differences may depend on grain kernel structure, the pericarp of cereal grains, the structure of starch (amylose to amylopectin ratio), and the presence of other nutrient contents in the grain (e.g., protein, fat, and fiber) that can bond with starch molecules. The grain's physical structure and outer layers affect the digestibility of starch in the gastrointestinal tract and are often impermeable to water and bacterial degradation (Moharrery et al., 2014). Moreover, the different characteristics of starch granules could considerably influence the ability of isolated amylolytic enzymes to digest starch and, thus, affect starch degradability in the rumen (Zhang et al., 2005). Several previous studies found that the amylose/amylopectin ratio correlates negatively with starch digestion in animals. Zhang et al. (2005) found that high amylopectin and type B starch (long-chain amylopectin) content in cassava starch resulted in high solubility in water, similar to our results at $0 \mathrm{~h}$ of incubation when cassava showed higher solubility than corn. Temperature and $\mathrm{NaOH}$ treatment led to the decreased solubility and degradability of cassava starch. This was explained by gelatinization and debranching of amylopectin, which caused the increased levels of amylose in the starch (Shi et al., 2011). Gelatinization at high temperature and with $\mathrm{NaOH}$ treatment and retrogradation when re-cooling led to the reduced solubility and degradability of starch in the rumen; however, the degradability of corn in the rumen increased when steam and $\mathrm{NaOH}$ treatment were applied. The results observed in our trial can be explained by the disruption of the corn grain cuticular protein matrix. Shen et al. (2015) found that in situ digestion results showed the greater starch degradability of steam-flake corn than ground corn $(66.9 \%$ vs $46.9 \%)$. Moharrery et al. (2014) reported that more severe processing methods aimed at modifying the physical structure, such as steam and flaking, disrupted the protein matrix of corn and sorghum and increased the rumen degradability of 
starch within the vitreous endosperm. Kung et al. (1983) studied whole corn treated with $\mathrm{NaOH}$ in laboratory trials. DM disappearances from nylon bags in the rumen of whole corn treated with $2.5,3.5$, or $4.9 \% \mathrm{NaOH}$ for $30 \mathrm{~h}$ were measured at $59.6 \%, 72.4 \%$, and $93.0 \%$, respectively, compared with $82.2 \%$ for untreated ground corn.

For in situ degradation, the results of this experiment indicated that treating with steam and $\mathrm{NaOH}$ treatments decreased solubility $\left(a_{\mathrm{is}}\right)$ and effective degradability $\left(E D_{\text {is }}\right)$ of starch from cassava chips in the rumen. Our results showed an apparent DMD that significantly decreased DM loss in the rumen during treatment with cassava chips. Moreover, corn grain treated with steam and $\mathrm{NaOH}$ increased the ability of degradation in the rumen, as confirmed by the DM disappearance in all treated corn grain that showed a greater DM degradability in the rumen than untreated corn grain. Shen et al. (2015) conducted an in situ digestibility test and found that steamed corn grain had greater starch degradability, $c_{i s^{\prime}}$ and $\mathrm{ED}_{\text {is }}$ than untreated corn grain. Ahmadijoo et al. (2020) found higher digestibility and rumen fermentation profiles when the cows fed steam flaked corn and barley grains. Karami et al. (2018) hypothesized that increased starch degradability of steamed corn grain might be caused by the disruption of the protein matrix surrounding the endosperm starch granules and disorganization in the starch granules. In our experiment, high steaming temperatures and alkalosis might have disrupted the strong physical covering around the corn grain, decreasing water solubility and increasing microbial digestion in the rumen.

Treatment methods that used steam and $\mathrm{NaOH}$ enhanced the degradability of NFC, resulting in the decreased bypass NFC in corn grain. Treatment methods increased the bypass CP and NFC of cassava chips to between $51.91 \%$ and $71.07 \%$ and $148.04 \%$ and $158.26 \%$, respectively. In addition, the treatment methods reduced the bypass CP and NFC of corn grain by $12.14 \%$ to $13.53 \%$ and $11.54 \%$ to $21.28 \%$, respectively. Savari et al. (2018) reported that corn grain was almost completely resistant to microbial fermentation in the rumen, whereas grinding and steam processing methods have been used to improve ruminal carbohydrate availability in dairy cattle (Shen et al., 2015). Chemical and physical changes in corn starch granules might be induced by manipulative factors such as moisture, temperature, pressure, and thermal alkalinity to increase the proportion of starch digested in the rumen (Zhong et al., 2008). Conversely, we found that the same methodology with treated corn grain had a different effect on treated cassava chips. Treated cassava chips showed the decreased ruminal digestion of $\mathrm{CP}$ and NFC and the increased bypass $\mathrm{CP}$ and NFC compared with untreated cassava chips. These different results can be explained by diverse physical and chemical starch structures in corn grain and cassava chips. The non-protein seed coat of corn grain was easily gelatinized with the occurrence of starch aging recrystallization (Israkarn et al., 2014). The major source of starch can be gelatinized by heat or $\mathrm{NaOH}$ addition. Li \& Lim (2016) determine that thermal alkalinity is an efficient catalyst for chemical modifica- tion of starch by inflating the crystalline region and promoting starch gelatinization and amylose leaching from the granule (Wang \& Copeland, 2012), thus reducing the proportion of amylopectin in cassava starch (Cai et al., 2014). Reducing the amylopectin content in cassava starch resulted in limited water solubility and increased starch recrystallization after gelatinization to form a resistant starch molecule that prevented the risk of starch digestion by ruminal microorganisms.

In vitro gas production characteristics, the gas production rate of high-starch cassava chips was higher than that of corn grain. Nitipot \& Sommart (2003) studied in vitro gas production techniques. They found that cassava chips' gas production rate and effective gas production potential were higher than that of cornmeal, broken rice, and other industrial by-products. In terms of treatment methods, the $\mathrm{EP}_{\text {gas }}$ fraction decreased in the treated group compared with the control group. This result concurred with the degradability trial by the in situ nylon bag technique, which showed significantly decreased $\mathrm{ED}_{\text {is }}$ in treated cassava chips compared to untreated cassava chips. However, gas production was higher in treated corn grain. Karami et al. (2018) found that the gas production of steamed corn grain was higher than that of untreated corn grain. Gas production increased after treatment because $\mathrm{NaOH}$ or steam treatment caused starch gelatinization, disrupted intermolecular hydrogen bonds, and enhanced the corn kernel surface that was available for rumen microbial attachment. Gases were produced from the degradation of carbohydrates into volatile fatty acids and carbon dioxide $\left(\mathrm{CO}_{2}\right)$. The greater ruminal digestion of starch is associated with the high gas production in the rumen (Ungerfeld, 2020).

The inclusion of gas production characteristics in the regression equation improved the prediction accuracy of in situ characteristics. Especially, the fraction of $\mathrm{EP}_{\text {gas }}$ in the regression equation increased the accuracy of predicting $\mathrm{ED}_{\text {is }}$ in in situ characteristics of combined high-starch energy feeds. Cone et al. (1999) presented a close relationship $\left(\mathrm{R}^{2}=88.0 \%\right)$ found in in situ and in vitro gas production characteristics for silage samples. Kamalak et al. (2005) also noted a significant correlation between gas production and in situ DM disappearance and suggested the equation to predict effective DM degradability (EDMD) of roughage using gas kinetics. Insoluble fraction (b) alone explained $98.3 \%$ of the EDMD variation. With these high-starch energy feeds, either the in situ DMD or the in vitro gas production technique could be used to assess starch fermentation in the rumen since there was a very good positive relationship between the two techniques. The highly significant relationship suggested that $\mathrm{ED}_{i s}$ can be predicted from $\mathrm{EP}_{\mathrm{gas}}$. Significant observations in the experiment indicate that the in vitro gas production technique can be applied to study the extent of DM degradation of high-starch energy feeds, instead of the in situ technique, which may have advantages in many aspects such as being less dependent on animals, avoiding the error associated with the loss of small particles through the pores of the bag, and reducing the inputs and the cost of labor. 


\section{CONCLUSION}

Treating cassava chips with steam and $\mathrm{NaOH}$ decreased ruminal degradability, leading to the increased bypass protein and NFC, whereas treating corn grain increased ruminal degradability, resulting in the decreased bypass protein and NFC. It is noteworthy that the different physical and chemical structures of corn grain and cassava chips have varied effects on the capacity for starch degradation in the rumen. Nevertheless, the in vitro study results should be applied to in vivo studies to assess any responses in ruminants.

\section{CONFLICT OF INTEREST}

The authors declare that they have no conflict of interest.

\section{ACKNOWLEDGEMENT}

The authors would like to express heartfelt thanks to the Royal Golden Jubilee (RGJ) Ph.D. program, the Agricultural Research Development Agency (ARDA), and the Increase Production Efficiency and Meat Quality of Native Beef and Buffalo Research Group, Khon Kaen University for financial support. We would also like to express our sincere thanks to the Department of Animal Science, Faculty of Agriculture, Khon Kaen University for facilities support.

\section{REFERENCES}

Ahmadijoo, N., H. Mansoori-Yarahmadi, J. Fakhraei, \& M. Changizi. 2020. Reproductive responses, metabolic disorder, ruminal fermentation characteristics, and milk production of postpartum Holstein cows fed steam flaked of corn and barley grains. Trop. Anim. Sci. J. 43:240-247. https://doi.org/10.5398/tasj.2020.43.3.240

AOAC. 2005. The Association of Official Analytical Chemists, $18^{\text {th }}$ ed. Assoc. Off. Anal. Chem., Arlington.

Aschenbach, J. R., G. B. Penner, F. Stumpff, \& G. Gabel. 2011. Ruminant nutrition symposium: Role of fermentation acid absorption in the regulation of ruminal $\mathrm{pH}$. J. Anim. Sci. 89:1092-1107. https://doi.org/10.2527/jas.2010-3301

Bhuiyan, M. M., F. Islam, A. J. Cowieson, \& P. A. Iji. 2012. Effect of source and processing on maize grain quality and nutritional value for broiler chickens 1 . Heat treatment and physiochemical properties. Asian J. Poult. Sci. 6: 101-116. https://doi.org/10.3923/ajpsaj.2012.101.116

Cai, J., Y. Yang, J. Man, J. Huang, Z. Wang, C. Zhang, M. Gu, Q. Liu, \& C. Wei. 2014. Structural and functional properties of alkali-treated high-amylose rice starch. Food Chem. 145:245-253. https://doi.org/10.1016/j. foodchem.2013.08.059

Calsamiglia, S., \& M. D. Stern. 1995. A three-step in vitro procedure for estimating intestinal digestion of protein in ruminants. J. Anim. Sci. 73:1459-1465. https://doi. org/10.2527/1995.7351459x

Cone, J. W., A. H. Van Gelder, I. A. Soliman, H. De Visser, \& A. M. Van Vuuren. 1999. Different techniques to study rumen fermentation characteristics of maturing grass and grass silage. J. Dairy Sci. 82:957-966. https://doi.org/10.3168/jds. S0022-0302(99)75315-4

Domby, E. M., U. Y. Anele, K. K. Gautam, J. E. Hergenreder,
A. R. Pepper-Yowell, \& M. L. Galyean. 2014. Interactive effects of bulk density of steam-flaked corn and concentration of Sweet Bran on feedlot cattle performance, carcass characteristics, and apparent total tract nutrient digestibility. J. Anim. Sci. 92:1133-43. https://doi.org/10.2527/ jas.2013-7038

Fernandes, T., M. A. Zambom, D. D. Castagnara, L. D. Souza, D. O. Damasceno, \& E. L. Schmidt. 2015. Use of dried waste of cassava starch extraction for feeding lactating cows. An. Acad. Bras. Cienc. 87:1101-1111. https://doi. org/10.1590/0001-3765201520140220

Gonzalez-Rivas, P. A., K. DiGiacomo, P. A. Giraldo, B. J. Leury, J. J Cottrell, \& F. R. Dunshea. 2017. Reducing rumen starch fermentation of wheat with three percent sodium hydroxide has the potential to ameliorate the effect of heat stress in grain-fed wethers. J. Anim. Sci. 95:5547-5562. https://doi.org/10.2527/jas2017.1843

Huntington, G. B. 1997. Starch utilization by ruminants: From basics to the bunk. J. Anim. Sci. 75:852-867. https://doi. org/10.2527/1997.753852x

Israkarn, K., N. Nakornpanom, \& P. Hongsprabhas. 2014. Physicochemical properties of starches and proteins in alkali-treated mungbean and cassava starch granules. Carbohydr. Polym. 105:34-40. https://doi.org/10.1016/j. carbpol.2014.01.054

Kamalak, A., O. Canbolat, Y. Gurbuz, \& O. Ozay. 2005. Comparison of in vitro gas production technique. Czech J. Anim. Sci. 50:60-67. https://doi.org/10.17221/3996-CJAS

Kanjanapruthipong, J., N. Buatoug, U. Kanto, S. Juttupornpong, \& W. Chaw-uthai. 2001. Cassava chips and ground corn as sources of total non-fiber carbohydrates in total mixed rations for dairy cow. Asian-Australas. J. Anim. Sci. 14:206210. https://doi.org/10.5713/ajas.2001.206

Karami, M., M. H. Palizdar, \& M. S. Almasi. 2018. The effect of different processing of corn grain on gas production kinetics and in vitro digestibility in Taleshi cows. J. Livest. Sci. 9:101-106

Kung, L. Jr., B. W. Jesse, J. W. Thomas, J. T. Huber, \& R. S. Emery. 1983. High moisture ground ear corn high moisture barley or sodium hydroxide mated barley for lactating cows: milk production and ration utilization. Can. J. Anim. Sci. 63:15-23. https://doi.org/10.4141/cjas83-018

Li, Y. \& S. Lim. 2016. Preparation of aqueous alpha-lipoic acid dispersions with octenylsuccinylated high amylose starch. Carbohydr. Polym. 140:253-259. https://doi.org/10.1016/j. carbpol.2015.12.023

Ma, D., J. Li, C. Huang, F. Yang, Y. Wu, L. Liu, W. Jiang, Z. Jia, P. Zhang, X. Liu, \& S. Zhang. 2019. Determination of the energy contents and nutrient digestibility of corn, waxy corn and steam-flaked corn fed to growing pigs. Asian-Australas. J. Anim. Sci. 32:1573-1579. https://doi. org/10.5713/ajas.18.0713

Menke, K. H., \& H. Steingass. 1988. Estimation of the energetic feed value obtained from chemical analysis and gas production using rumen fluid. Anim. Res. Dev. 28:7-55.

Mertens, D. R. 1997. Creating a system for meeting the fiber requirements of dairy cows. J. Dairy Sci. 80:1463-1481. https://doi.org/10.3168/jds.S0022-0302(97)76075-2

Metzler-Zebeli, B. U., M. Hollmann, S. Sabitzer, L. PodstatzkyLichtenstein, D. Klein, \& Q. Zebeli. 2013. Epithelial response to high-grain diets involves alteration in nutrient transporters and $\mathrm{Na}+/ \mathrm{K}+-$ ATPase mRNA expression in rumen and colon of goats. J. Anim. Sci. 91:4256-4266. https:// doi.org/10.2527/jas.2012-5570

Moharrery, A., M. Larsen, \& M. R. Weisbjerg. 2014. Starch digestion in the rumen, small intestine, and hind gut of dairy cows - A metaanalysis. Anim. Feed Sci. Technol. 192:1-14. https://doi.org/10.1016/j.anifeedsci.2014.03.001

Nitayavardhana, S., P. Shrestha, M. L. Rasmussen, B. P. 
Lamsal, J. van Leeuwen, \& S. K. Khanal. 2010. Ultrasound improved ethanol fermentation from cassava chips slurry in cassava-based ethanol plants. Biores. Technol. 101:27412747. https://doi.org/10.1016/j.biortech.2009.10.075

Nitipot, P. \& K. Sommart. 2003. Evaluation of ruminant nutritive value of cassava starch industry by products, energy feed sources and rouges using in vitro gas production technique. In: Proceedings of Annual Agricultural Seminar for year 2003. Khon Kaen, Thailand. p. 179-190.

NRC. 2001. Nutrient Requirements of Dairy Cattle. $7^{\text {th }}$ rev. ed. National Academic Science, Washington, DC.

Ørskov, E. R., \& I. McDonald. 1979. The estimation of protein degradability in the rumen from incubation measurements weighted according to rate of passage. J. Agric. Sci. 92:499503. https://doi.org/10.1017/S0021859600063048

Palacios-Fonseca, A. J., J. Castro-Rosas, C. A. Gómez-Aldapa, T. TovarBenítez, B. M. Millán-Malo, A. del Real, \& M. E. Rodríguez-García. 2013. Effect of the alkaline and acid treatments on the physicochemical properties of corn starch. J. Food Sci. 11:67-74. https://doi.org/10.1080/19476 337.2012.761651

Perez-Carrillo, E., C. M. Luisa, L. E. Sabillo'n-Galeas, J. L. Montalvo-Villarreal, J. R. Canizo, M. M. Georgina, \& S. O. Serna-S. 2011. Detrimental effect of increasing sugar concentrations on ethanol production from maize or decorticated sorghum mashes fermented with Saccharomyces cerevisiae or Zymomonas mobilis. Biotechnol. Lett. 33:301307. https://doi.org/10.1007/s10529-010-0448-9

Pilachai, R., J. T. Schonewille, C. Thamrongyoswittayakul, S. AiumLamai, C. Wachirapakorn, H. Everts, \& W. H. Hendriks. 2012. The effects of high levels of rumen degradable protein on rumen $\mathrm{pH}$ and histamine concentrations in dairy cows. J. Anim. Physiol. Anim. Nutr. 96:206213. https://doi.org/10.1111/j.1439-0396.2011.01139.x

Pilachai, R., W. Kaewwongsa, A. Petlum, Y. Chumpol, \& W. Thongdee. 2014. Rumen digestibility of lactic acid steeped cassava using nylon bag technique. Khon Kaen Agric. J. 42:567-576.

Pilachai, R., W. Thongdee, Y. Chumpol, S. Seesupa, \& J. T. Schonewille. 2017. Effects of proportion of cassava and lactic acid-treated cassava in rations on rumen $\mathrm{pH}$ and plasma lipopolysaccharide-binding protein in beef cattle. Thai J. Vet. Med. 47:173-181.

Sarocha. P., J. Ankita, B. Muhammad, N. Athapol, \& S. Vijay. 2018. Comparison of cassava starch with corn as a feedstock for bioethanol production. Energies. 11:3476-3487. https://doi.org/10.3390/en11123476

SAS. 1998. User's Guide: Statistics, Version6. $12^{\text {nd }}$ Ed. SAS Inst. Inc., Cary, NC.

Savari, M., M. Khorvash, H. Amanlou, G. R. Ghorbani, E. Ghasemi, \& M. Mirzaei. 2018. Effects of rumen-degradable protein: rumen-undegradable protein ratio and corn processing on production performance, nitrogen efficiency, and feeding behavior of Holstein dairy cows. J. Dairy Sci. 101:1111-1122. https://doi.org/10.3168/jds.2017-12776

Shen, J. S., L. J. Song, H. Z. Sun, B. Wang, Z. Chai, B. Chacher, \& J. X. Liu. 2015. Effects of corn and soybean meal types on rumen fermentation, nitrogen metabolism and productivity in dairy cows. J. Anim. Sci. 28:351-359. https:// doi.org/10.5713/ajas.14.0504

Shi, A. M., D. Li, L. J. Wang, B. Z. Li, \& B. Adhikari. 2011. Preparation of starch-based nanoparticles through highpressure homogenization and miniemulsion cross-linking: Influence of various process parameters on particle size and stability. Carbohydr. Polym. 83:1604-1610. https://doi. org/10.1016/j.carbpol.2010.10.011

Silva, C. A., N. D. Sousa, S. M. E. Silva, P. T. Fontes, \& S. R. Tomaz. 2016. Optimal consumes of $\mathrm{NaOH}$ in starches gelatinization for froth flotation. Int. J. Environ. Eng. 10:994999. https://doi.org/10.5281/zenodo.1127204

Singh, N., A. Kaur, \& K. Shevkani. 2013. Maize: Grain structure, composition, milling, and starch characteristics. In: Chaudhary D., Kumar S., Langyan S. (Eds.) Maize: Nutrition Dynamics and Novel Uses. Springer, New Delhi. 2013:65-76. https://doi.org/10.1007/978-81-322-1623-0_5

Sommart, K., M. Wanapat, P. Rowlinson, D. S. Parker, P. Climee, \& S. Panishying. 2000. The use of cassava chips as an energy source for lactating dairy cows fed with rice straw. Asian-Australas. J. Anim. Sci. 13:1094-1101. https:// doi.org/10.5713/ajas.2000.1094

Srakaew, W., C. Wachirapakorn, \& C. Wongnen. 2021. Dietary modified cassava chips and corn seed: Effect on growth performance, rumen production, and blood glucose and insulin in early fattening beef bulls. Walailak J. Sci. Technol. 18: Article 9217. https://doi.org/10.48048/wjst.2021.9217

Steel, R. G. \& J. H. Torrie. 1980. Analysis of covariance. Principles and procedures of statistics: A Biometrical Approach. McGraw-Hill Book Company, Inc., New York. p. $401-437$.

Suksombat, W., P. Lounglawan, \& P. Noosen. 2007. Energy and protein evaluation of five feedstuffs used in diet in which cassava pulp as main energy source for lactating dairy cows. Suranaree J. Sci. Technol. 14:99-107.

Ungerfeld, E. M. 2020. Metabolic hydrogen flows in rumen fermentation: Principles and possibilities of interventions. Front. Microbiol. 11:589. https://doi.org/10.3389/ fmicb.2020.00589

Van Soest, P. J., J. B. Robertson, \& B. A. Lewis. 1991. Methods for dietary fiber, neutral detergent fibre and nonstarch polysaccharide in relation to animal nutrition. J. Dairy Sci. 74:3583-3597. https://doi.org/10.3168/jds. S0022-0302(91)78551-2

Wang, S., \& L. Copeland. 2012. Effect of alkali treatment on structure and function of pea starch granules. Food Chem. 135:1635-1642. https://doi.org/10.1016/j. foodchem.2012.06.003

Zhang, P., R. L. Whistler, R. L. BeMiller, \& R. L. Hamaker. 2005. Banana starch: production, physicochemical properties, and digestibility - a review. Carbohydr. Polym. 59:443-458. https://doi.org/10.1016/j.carbpol.2004.10.014

Zhong, R. Z., J.G. Li, Y. X. Gao, Z. L. Tan, \& G. P. Ren. 2008. Effects of substitution of different levels of steam-flaked corn for finely ground corn on lactation and digestion in early lactation dairy cows. J. Dairy Sci. 91:3931-3937. https://doi.org/10.3168/jds.2007-0957 